\title{
PENGARUH MOTIVASI TERHADAP PRESTASI KERJA KARYAWAN DI PDAM TIRTA MUSI UNIT RAMBUTAN PALEMBANG
}

\author{
Eni Cahyani \\ Dosen Politeknik Anika Palembang
}

\begin{abstract}
ABSTRAK
Penelitian ini untuk mengetahui ada tidaknya pengaruh motivasi kerja terhadap prestasi karyawan Bagian Produksi I PDAM Tirta Musi Unit Rambutan Palembang. Penelitian ini adalah penelitian kuantitatif data yang digunakan data primer dan sekunder, metode dan teknik menggunakan Studi pustaka, dengan mengadakan studi penelaahan terhadap buku-buku, literaturliteratur, catatan-catatan, dan penyebarab melalui Angket (kuesioner. Populasi masyarakat kec. Sukarami berjumlah 40 orang. Teknik analisis regresi sederhana, dengan melakukan uji validitas, reliabilitas, uji asumsi klasik dan hipotesis. Hasil pengujian regresi linier sederhana terbentuk persamaan $\mathrm{Y}=21,077+0,283 \mathrm{X}$, dengan nilai koefisien determinasi $\left(\mathrm{R}^{2}\right)$ sebesar 0,73 atau 73,0\%, menunjukkan bahwa pengaruh motivasi kerja terhadap prestasi karyawan Bagian Produksi I PDAM Tirta Musi Unit Rambutan Palembang sebesar 73,0 \% sedangkan sisanya 27,0 $\%$ dijelaskan oleh variabel lain yang tidak termasuk dalam penelitian ini.
\end{abstract}

\section{Kata Kunci : Motivasi, Prestasi Kerja}

\section{PENDAHULUAN}

\section{I.1. Latar Belakang Masalah}

Kualitas mansia sebagai tenaga kerja merupakan modal dasar dalam masa pembangunan. Tenaga kerja yang berkualitas akan menghasilkan suatu hasil kerja yang optimal sesuai dengan target kerjanya. Manusia sebagai tenaga kerja atau karyawan merupakan sumber daya yang penting bagi perusahaan, karena mereka mempunyai bakat, tenaga dan kreativitas yang sangat dan dibutuhkan oleh perusahaan untuk mencapai tujuannya. Sebaliknya Sumber Daya Manusia juga mempunyai berbagai macam kebutuhan yang ingin dipenuhinya. Keinginan para karyawan untuk memenuhi kebutuhan inilah yang dapat memotivasi seseorang untuk melakukan sesuatu termasuk untuk melakukan pekerjaan atau beker ja. Pemberian Motivasi sangat penting bagi karyawan, karena motivasi merupa kan ukuran terhadap prestasi kerja karyawan, maka apabila Motivasi yang diberikan cukup, akan mendorong karyawan untuk lebih baik dalam melakukan pekerjaannya dan lebih bertanggung jawab atas masingmasing tugas yang diberikan perusahaan.

Motivasi berasal dari kata "movere" yang berarti "dorongan atau daya penggerak “. Dalam menjalankan hidup, seseorang memerlukan banyak motivasi agar ia dapat menjalankan segala sesuatu yang dapat mempertahankan kelangsungan hidupnya. Dalam dunia pendidikan, seseorang anak memerlukan motivasi baik dari orang tua ,guru, maupun teman- temannya agar ia mampu meningkatkan prestasi belajarnya. Hal ini pula yang dibutuhkan orang dalam dunia kerja. Seseorang hanya dapat bekerja dengan baik apabila ia mendapatkan motivasi kerja yang baik pula. Motivasi 
kerja tidak hanya bersumber dari dalam diri orang itu saja, melainkan memerlukan perpaduan baik dari diri sendiri, atasan, maupun lingkungan kerja itu sendiri. Motivasi kerja menyebabkan pelaksanaan kerja dan pencapaian prestasi yang lebih baik atau sebaliknya.

Prestasi kerja merupakan salah satu indicator keberhasilan operasi perusahaan dalam pencapaian tujuannya. Salah satu usaha yang tepat untuk dilakukan agar mereka mau bekerja dengang giat adalah memberikan motivasi.

Menurut Hasibuan (2012: 141), Motivasi mempersoalkan bagaimana caranya mengarahkan daya dan potensi bawahan, agar mau bekerja sama secara produktif berhasil mencapai dan mewujudkan tujuan yang telah ditentukan. Malayu S.P. Hasibuan (2008 : 94), menjelaskan bahwa "Prestasi kerja yaitu suatu hasil kerja yang dicapai seseorang dalam melaksanakan tugas-tugas yang dibebankan kepadanya yang didasarkan atas kecakapan dan kesungguhan serta waktu. Sedang timbulnya prestasi dipengaruhi oleh beberapa faktor pendorong, baik yang berasal dari luar individu maupun dari dalam individu. Daya perangsang, daya pendorong, motivasi yang mendorong karyawan untuk mau ikut bekerja dengan giat berbeda antara karyawan satu dengan lainnya. Perbedaan ini disebabkan oleh perbedaan motif, tujuan, dan kebutuhan masing - masing karyawan untuk bekerja. Untuk itu kebutuhan karyawan baik bersifat material maupun non material hendaknya dipenuhi sesuai dengan harapannya apabila prestasi kerja karyawan diharapkan tinggi.

Perusahaan Daerah Air Minum (PDAM) Tirta Musi Palembang merupakan Badan Usaha Milik Daerah (BUMD) bergerak dibidang pelayanan penyediaan air minum kepada masyarakat kota Palembang dengan kualitas dan kuantitas yang sesuai dengan standar yang di tetapkan, yang didirikan pada tanggal 3 april 1976. kantor pusat PDAM Tirta Musi Palembang yang beralamat Komp. Rambutan Ujung No. 1 Palembang. Berdasarkan uraian di atas, penulis tertarik untuk melakukan penelitian yang berjudul " PENGARUH MOTIVASI TERHADAP PRESTASI KERJA KARYAWAN DI PDAM TIRTA MUSI UNIT RAMBUTAN".

\subsection{Perumusan Masalah}

Berdasarkan uraian latar belakang maka permasalahan yang akan dibahas dalam penelitian ini adalah "Bagaimana Pengaruh Motivasi terhadap Prestasi Kerja karyawan di bagian produksi I PDAM Tirta Musi Unit Rambutan Palembang.

\subsection{Tujuan Penelitian}

Tujuan dari Penelitian ini adalah untuk mengetahui ada tidaknya pengaruh motivasi kerja terhadap prestasi karyawan Bagian Produksi I PDAM Tirta Musi Unit Rambutan Palembang.

\section{TINJAUAN PUSTAKA}

\subsection{Pengertian Motivasi}

Seseorang yang tidak termotivasi, hanya memberikan upaya minimum dalam hal bekerja. Konsep motivasi, merupakan sebuah konsep penting studi tentang kinerja individual. Dengan demikian motivasi berati pemberian dorongan, penimbulan motiv atau hal yang menimbulkan dorongan atau keadaan yang menimbulkan dorongan. Dapat juga dikatakan bahwa motivasi adalah faktor yang mendorong orang untuk bertindak dengan cara tertentu.

\subsection{Definis Motivasi}

Mangkunegara

(2005:61)

menyatakan motivasi terbentuk dari sikap (attitude) karyawan dalam menghadapi situasi kerja di perusahaan (situation). Motivasi merupakan kondisi atau energi 
yang menggerakkan diri karyawan yang terarah atau tertuju untuk mencapai tujuan organisasi perusahaan. Sikap mental karyawan yang pro dan positif terhadap situasi kerja itulah yang memperkuat motivasi kerjanya untuk mencapai kinerja maksimal.

Menurut Hasibuan (2003:92) motivasi berasal dari kata lain movere yang berarti dorongan atau daya penggerak. Motivasi ini hanya diberikan kepada manusia, khususnya kepada para bawahan atau pengikut. Motivasi penting karena dengan motivasi ini diharapkan setiap individu karyawan mau bekerja keras dan antusias untuk mencapai produktivitas kerja yang tinggi. Sedangkan pendapat lain mengatakan motivasi adalah keinginan yang terdapat pada seorang individu yang merangsang untuk melakukan tindakan (Winardi,2000:312). Berbagi pendapat dapat di simpulkan bahwa motivasi adalah dorongan yang timbul dari dalam diri setiap individu, tanpa ada paksaan dari siapapun untuk melakukan suatu pekerjaan.

\subsection{Tujuan Motivasi}

Adapun tujuan Motivasi menurut Hasibuan (2000:145) adalah sebagai berikut:

1. Meningkatkan moral dan kepuasan kerja karyawan

2. Meningkatkan produktivitas kerja karyawan

3. Meningkatkan kedisiplinan karyawan

4. Mempertahankan kestabilan karyawan perusahaan

5. Mengefektifitaskan pengadaan karyawan

6. Menciptakan dan hubungan kerja yang baik

7. Meningkatkan loyalitas, kretivitas dan partisipasi karyawan

8. Meningkatkan tingkat kesejahteraan karyawan

9. Mempertinggi rasa tanggung jawab karyawan terhadap tugas - tugasnya
10. Meningkatkan efisiensi penggunaan alat - alat bahan baku

\subsection{Prinsip - prinsip Dalam Motivasi}

Pemimpin memberikan perhatian kepada pegawai bawahan dalam bekerja dengan memberikan apa yang diinginkan pegawai tersebut untuk menunjang pekerjaannya Didalam bukunya Mangkunegara (2011-100) memaparkan satu persatu prinsip - prinsip dalam memotivasi pegawai, yaitu :

1. Prinsip Partisipasi. Dalam upaya memotivasi kerja, pegawai perlu diberikan kesempatan ikut berpartisipasi dalam menentukan tujuan yang akan dicapai oleh pemimpin.

2. Prinsip Komunikasi.

3. Pemimpin mengkomunikasikan segala yang berhubungan dengan usaha pencapaian tujuan, dengan informasi yang jelas, pegawai akan lebih mudah dimotivasikan kerjanya.

4. Prinsip Mengakui Andil bawahan.

5. Pemimpin mengakui bahwa bawahan (pegawai) mempunyai andil didalam usaha pencapaian tujuan. Dengan pengakuan tersebut pegawai akan termotivasi untuk berdedikasi lebih tinggi dalam pekerjaannya.

6. Prinsip Pendelegasian Wewenang.

7. Pemimpin yang memberikan otoritas atau wewenang kepada pegawai untuk sewaktu - waktu dapat mengambil keputusan terhadap pekerjaan yang dilakukannya, akan membuat pegawai yang bersangkutan menjadi termotivasi dalam bekerja.

8. Prinsip Memberi Perhatian

9. . Hal tersebut akan memotivasikan pegawai tersebut dalam bekerja. 


\subsection{Faktor-faktor yang mempengaruhi Motivasi}

Menurut Frederick Herzberg (1996)

dalam Robbins (2008: 218) ada dua jenis faktor yang mempengarhi motivasi kerja, yaitu faktor Intrinsik dan faktor ekstrinsik.

1) Faktor-Faktor Intrinsik yang berkaitan dengan isi pekerjaan, antara lain:

a. Tanggung Jawab (Responsibility), besar kecilnya tanggung jawab yang dirasakan dan diberikan kepada seorang karyawan.

b. Kemajuan (Advancement), ir kecilnya kemungkinan karyawan dapat maju dalam pekerjaannya.

c. Pekerjaan Itu Sendiri (The work itself), besar kecilnya tantangan yang dirasakan oleh karuawan dari pekerjaannya.

d. Pencapaian (Achievement), besar kecilnya kemungkinan karyawan mendapatkan prestasi kerja, mencapai kinerja tinggi.

e. Pengakuan (Recognition), besar kecilnya pengakuan yang diberikan kepada karyawan atas kinerja yang dicapai.

2) Faktor-Faktor Ekstrinsik yang menimbulkan ketidakpuasan serta berkaitan dengan konteks pekerjaan, antara lain:

a. Kebijakan dan Administrasi perusahaan (Company Policy and Administration), derajat kesesuaian yang dirasakan karyawan dari semua kebijakan dan peraturan yang berlaku dalam organisasi.

b. Kondisi kerja (Working Condition), derajat kesesuaian kondisi kerja dengan pelaksanaan tugas pekerjaannya.

c. Gaji dan Upah (Wages and Salaries), derajat kewajaran dari gaji yang diterima sebagai imbalan kinerjanya. d. Hubungan Antar Pribadi (Interpersonal Relation), derajat kesesuaian yang dirasakan dalam berinteraksi dengan karyawan lain.

e. Kualitas supervisi (Quality Supervisor), derajat kewajaran penyeliaan yang dirasakan dan diterima oleh karyawan. (Michael dan Intan, 2010: 25-26)

\subsection{Pengertian Prestasi Kerja}

Menurut Prabu (2009) dalam Sutrisno (2010:151) menyatakan bahwa prestasi kerja adalah hasil kerja secara kualitas dan kuantitas yang dicapai oleh seseorang pegawai dalam melaksanakan tugas sesuai tanggung jawab yang diberikan kepada pegawai tersebut.

Hasibuan (2007) dalam Sutrisno (2010:151) menyatakan bahwa prestasi kerja adalah suatu hasil kerja yang dicapai seseorang dalam melaksanakan tugas-tugas yang dibebankan kepada pegawai yang didasarkan atas kecakapan, pengalaman, dan kesungguhan serta waktu.

Malayu S.P. Hasibuan (2008 : 94), menjelaskan : "Prestasi kerja adalah suatu hasil kerja yang dicapai seseorang dalam melaksanakan tugas-tugas yang dibebankan kepadanya yang didasarkan atas kecakapan dan kesungguhan serta waktu.

\subsection{Penilaian Prestasi Kerja.}

Penilaian adalah waktu yang ideal untuk memusatkan sasaran individu, buka sasaran unit.Ini adalah peluang untuk menyentuh bagian dasar dan membandingkan hasil-hasil kerja dengan toak ukuar yang telah disepakati sebelumnya.Pimpinan memberikan penghargaan atas prestasi dan pekerjaan yang dilakukan dengan memuaskan karyawan diberi peluang untuk mengatakan kepada pimpinan alasan mereka tidak berprestasi seperti yang telah disepakati. Kemudian akan ada penilaian timbal balik 
mengapa sasaran dapat dipenuhi dan tidak dapat dipenuhi.

Menurut Nawawi (2005), pada hakekatnya penilaian prestasi kerja karyawan yang merupakan kegiatan manajemen SDM adalah suatu proses pengamatan (observasi) terhadap pelaksanaan pekerjaan oleh seorang pekerja yang memiliki hakhak asasi yang dilindungi. Menurut Hasibuan (2001) penilaian prestasi kerja adalah menilai rasio hasil kerja nyata dengan standar kualitas maupun kuantitas yang dihasilkan setiap karyawan, menetapkan kebijaksanaan mengenai promosi atau balas jasanya.

Menurut Sondang P. Siagian (2004:223) menjelaskan bahwa penilaian prestasi kerja karyawan para karyawan merupakan bagian seluruh proses karyawan pegawai yang bersangkutan. Pentingnya penilaian prestasikerja yang rasional dan ditetapkan secara obyektif terlihat pada paling sedikit dua kepentingan yaitu kepentingan pegawai yang bersangkutan sendiri dan organisasi. Dalam proses penilaian adalah untuk membuat karyawan memandang diri mereka seperti apa adanya, baik kebutuhan perilaku prestasi kerja maupun berperan serta dalam membuat rencana perbaikan prestasi kerja maupun berperan serta dalam membuat rencana perbaikan prestasi kerja. Dalam hal ini harus ada kesepakatan bersama tentang rencana pengembangan untuk masa penilaian mendatang.

Mangkunegara

(2001:ع

menyatakan bahwa penilaian prestasi kerja karyawan adalah suatu proses penilaian prestasi kerja karyawan yang dilakukan pemimpin perusahaan secara sistematik berdasarkan atas pekerjaan yang ditugaskan kepadanya. Anwar Prabu Mangkunegara (2009:67) berpendapat bahwa Prestasi kerja adalah hasil kerja secara kualitas dan kuantitas yang dicapai oleh seseorang pegawai dalam melaksanakan tugasnya sesuai dengan tanggung jawab yang diberikan kepadanya. Disisi lain Edwin B. Flippo (2012:22) mengatakan bahwa prestasi kerja seseorang dapat diukur melalui:

1. Mutu kerja yang berkaitan ketetapan waktu, keterampilan dan kepribadian dalam melakukan pekerjaan

2. Kuantitas kerja berkaitan dengan pemberian tugas-tugas kerja lembur.

3. Ketangguhan yang berkaitan dengan tingkat kehadiran, pemberian waktu libur, dan jadwal keterlambatan hadir ditempat kerja

4. Sikap merupakan sikap yang ada pada karyawan yang menunjukkan seberapa jauh sikap dan tanggung jawab mereka terhadap sesama teman dengan atasan dan seberapa jauh tingkat kerja samanya dalam menyelesaikan pekerjaan.

\subsection{Faktor-Faktor Yang Mempengaruhi Prestasi Kerja}

Menurut Steers dalam Rahmayanti (2007:46) faktor-faktor yang mempengaruhi prestasi kerja adalah:

a) Kemampuan.

b) Kepribadian dan minat kerja.

c) Tingkat kejelasan dan peran seorang pekerja.

d) Tingkat motivasi pekerja. Mangkunegara

(2001:67), menyatakan ada dua (2) faktor yang mempengaruhi pencapaian prestasi kerja, yaitu :

1. Faktor kemampuan Secara psikologis, kemampuan karyawan terdiri dari kemampuan potensi(IQ), dan kemampuan reality, artinya karyawan yang memiliki IQ diatas rata-rata dengan pendidikan yang memadai untuk jabatannya dan terampil dalam mengerjakan pekerjaan sehari-hari, maka ia akan 
lebih mudah dalam mencapai prestasi kerja yang diharapkan.

2. Faktor motivasi Motivasi terbentuk dari sikap seorang karyawan dalam menghadapi situasi kerja. Motivasi merupakan kondisi yang menggerakan diri karyawan yang terarah untuk mencapai tujuan organisasi.

Mathis dan Jakson (2002) menyatakan bahwa, prestasi kerja pada dasarnya adalah apa yang dilakukan atau tidak dilakukan karyawan. Prestasi kerja karyawan adalah yang mempengaruhi seberapa banyak mereka membei kontribusi kepada organisasi yang antara lain termasuk: (1) kuantitas output, (2) kualitas output, (3) jangka waktu output, (4) kehadiran di tempat kerja, dan (5) sikap kooperatif. Menurut Mangkunegara (2000) unsur-unsur yang dinilai dari prestasi kerja adalah kualitas kerja, kuantitas kerja, keandalan dan sikap. Kualitas kerja terdiri dari ketepatan, ketelitian, keterampilan, kebersihan. Kuantitas kerja terdiri dari output dan penyelesaian kerja dengan ekstra. Keandalan terdiri dari mengikuti instruksi, inisiatif, kehati-hatian, kerajinan. Sedangkan sikap terdiri dari sikap terhadap perusahaan, karyawan lain dan pekerjaan serta kerjasama.

\section{METODOLOGI PENELITAIN \\ 3.1. Objek Penelitian}

Objek Penelitiain ini adalah Perusahaan Air Minum Daerah (PDAM) Tirta Musi Unit Rambutan Palembang, di bagian produksi I yang beralamat di Jl. Rambutan ujung No.1 Palembang.

\subsection{Ruang Lingkup Penelitian}

Dalam penelitian skripsi ini penulis melakukan penelitian di PDAM Tirta Musi Unit Rambutan Palembang. Perusahaan ini adalah Perusahaan yang bergerak dibidang pelayanan penyediaan air minum kepada masyarakat kota Palembang. Perusahaan ini berlokasi di Jl. Rambutan Ujung No. 1 Palembang.

\subsection{Populasi}

Populasi adalah wilayah generalisasi yang terdiri atas obyek/subyek yang mempunyai kualitas dan karakteristik tertentu yang ditetapkan oleh peneliti untuk dipelajari dan kemudian ditarik kesimpulannya. Jadi populasi bukan hanya orang, tetapi juga obyek dan benda-benda alam yang lain. populasi bukan sekedar jumlah yang ada pada obyek/subyek yang dipelajari, tetapi meliputi seluruh karakteristik atau sifat yang dimiliki oleh subyek atau obyek itu (Sugiyono, 2011:117118). Populasi yang dilakukan oleh peneliti pada penelitian ini adalah karyawan bagian produksi 1 PDAM Tirta Musi Unit Palembang yaitu berjumlah 40 orang karyawan.

\subsection{Sampel}

Sampel adalah sebagian atau wakil populasi yang diteliti (Arikunto, 2006:131). Definisi lain dari sampel adalah bagian dari jumlah karakteristik yang dimiliki oleh populasi tersebut (Sugiyono, 2008:116). Sampel pada penelitian ini adalah semua populasi atau seluruh karyawan Bagian produksi I PDAM TIRTA MUSI unit Rambutan Palembang yang berjumlah 40 karyawan.

\subsection{Tehnik Analisis Data Analisis Deskritip Data}

Metode penganalisisan data dengan cara menyusun data, mengelompokkannya selanjutnya menginterprestasikannya sehingga diperoleh gambaran sebenarnya mengenai kondisi yang akan diteliti. 


\subsection{Uji Instrumen \\ - Uji Validitas}

Menurut Ghozali (2002:135), bahwa uji validitas digunakan untuk mengukur sah atau validnya suatu kuesioner. Suatu kuesioner dikatakan valid jika pernyataan pada kuesioner mampu untuk mengungkapkan sesuatu yang akan diukur oleh kuesioner tersebut. Contoh: meteran merupakan alat yang valid untuk mengukur satuan panjang. Meteran tersebut menjadi tidak valid jika digunakan untuk mengukur satuan berat pada suatu benda. Penelitian ini menggunakan alat kuisioner, oleh karena itu uji validasi dilakukan untuk menguji data yang telah didapat untuk mengetahui valid atau tidaknya data tersebut dengan menggunakan alat ukur kuisioner. Penguji validitas dilakukan dengan menggunakan program SPSS versi 20,00 dengan criteria sebagai berikut:

a. Jika $r$ hitung $>r$ tabel, maka pertanyaan dinyatakan valid.

b. Jika $\mathrm{r}$ hitung $>\mathrm{r}$ tabel, maka pertanyaan dinyatakan tidak valid/

\section{- Uji Reliabilitas}

Menurut Suryabrata (2004:28), realiabitas menunjukkan sejauh mana hasil pengukuran dengan alat tersebut dapat dipercaya. Hasil pengukuran harus realiabel dalam artian harus memiliki tingkat konsistensi dan kemantapan. Hasil suatu pengukuran dapat dipercaya apabila dalam beberapa kali pelaksanaan pengukuran terhadap subjek yang sama diperoleh hasil yang relative sama, artinya mempunyai konsistensi pengukuran yang baik, dan suatu konstruk atau variabel dikatakan reliable apabila memiliki Cronbach Alpa>0,60. Pengujian reliabitas instrument menggunakan pengujian satu skor pada taraf signifikan 5\%.

\section{- Analisis Deskriptif}

Metode analisis deskriptif merupakan cara merumuskan dan menafsirkan data yang ada sehingga memberikan gambaran yang nyata mengenai keadaan perusahaan melalui pengumpulan, penyusunan, dan penganalisaan data mengenai laporan keuangan dan kegiatan perusahaan, sehingga akan diketahui gambaran umum tentang perusahaan.

\subsection{Uji Regresi Sederhana}

Analisis ini menurut Sugiyono (2010:262), digunakan oleh peneliti bila peneliti bermaksud meramalkan bagaimana keadaan (naik turunnya) variabel dependen (kriterium), bila ada satu variabel independen sebagai prediktor dimanipulasi (dinaik turunkan nilainya). Untuk memperloleh hasil yang lebih terarah maka peneliti menggunakan regresi linear sederhana, sebagai berikut: Rumus persamaan regresi : $\mathrm{Y}=\mathrm{a}+\mathrm{bX}$

Keterangan:

$$
\begin{aligned}
& \mathrm{Y}=\text { Prestasi } \\
& \mathrm{a}=\text { Nilai intercept (konstan) } \\
& \mathrm{b}=\text { Koefisien regresi } \\
& \mathrm{X}=\text { Motivasi }
\end{aligned}
$$

\section{HASIL PENELITIAN DAN PEMBAHASAN}

\subsection{Hasil Uji Coba Instrumen Penelitian}

Peneliti mendapatkan data dengan membagikan kuesioner kepada pelanggan. Kriteria penilaian pemilihan ini di ukur dengan skala Likert. Menurut Sugiono (2006:80) pemilihan skala Likert didasarkan pada pertimbangan bahwa penelitian ini digunakan untuk mengukur sikap, pendapat dan persepsi responden tentang fenomena sosial yang ada disekitarnya. Kuesioner yang dibagikan secara langsung oleh penulis kepada responden yang ditemui secara langsung. Kuesioner yang akan digunakan dalam penelitian ini merupakan pernyataan mengenai pengaruh motivasi terhaadap prestasi kerja 
karyawan di. PDAM Tirta Musi Unit Rambutan Palembang.

\subsection{Distibusi Responden}

Responden dalam penelitian ini adalah karyawan di. PDAM Tirta Musi Unit Rambutan Palembang. populasinya berjumlah 40 orang. Dari jumlah tersebut sampel yang diambil sebesar 40 orang. - Responden menurut Tingkat Pendidikan

Tingkat pendidikan terakhir sangat mempengaruhi kemampuan dan tingkat kepercayaan diri seorang karyawan dalam melakukan pekerjaannya. Karyawan dengan pendidikan yang tinggi akan lebih mampu menyelesaikan pekerjaan dengan tingka kesulitan yang lebih tinggi daripada karyawan dengan tingkat pendidikan yang lebih rendah. Tanggung jawab dari karyawan dengan tingkat pendidikan yang tinggi biasanya juga jauh lebih tinggi karena mereka lebih dipercaya untuk menangani tingkat pekerjaan yang dianggap tidak mampu dikerjakan oleh karyawan yang kurang pengalaman, apalagi yang berpendidikan tidak terlalu tinggi. Data mengenai responden menurut tingkat pendidikan dapat dilihat pada tabel -2 berikut ini :

Tabel -2

Tingkat Pendidikan Responden

PDAM Tirta Musi Unit Rambutan Palembang.

\begin{tabular}{|c|c|c|}
\hline Tingkat Pendidikan & Jumlah & Persentase \% \\
\hline SMA & 17 & $\mathbf{4 3}$ \\
\hline D3 & 13 & $\mathbf{3 2}$ \\
\hline S1 & 10 & $\mathbf{2 5}$ \\
\hline & $\mathbf{4 0}$ & $\mathbf{1 0 0} \%$ \\
\hline
\end{tabular}

Sumber : PDAM Tirta Musi Unit Rambutan Palembang

Dari tabel-2 dapat dilihat bahwa tingkat pendidikan sebagian besar karyawan kantor PDAM Tirta Musi Unit Rambutan Palembang menjadi responden. Dalam penelitian adalah SMA yaitu berjumlah 17 orang atau 43\%. Kemudian S1 berjumlah 10 orang atau 25\% dan Diploma berjumlah 13 Orang atau $32 \%$.

\section{- Responden Menurut usia}

Usia seorang pegawai sangat menentukan kinerja secara keseluruhan. Pegawai dengan usia relatif masih muda akan mempunyai kemampuan fisik yang lebih baik daripada karyawan yang lebih tua. Akan tetapi seorang karyawan yang sudah berusia lebih tua akan mempunyai pengalaman yang tidak dimiliki oleh karyawan yang masih berusia muda. Oleh karena itu akan lebih baik apabila perusahaan menggabungkan atau memadukan karyawan berusia tua dengan usia muda. Data mengenai responden menurut umur dapat dilihat pada tabel -3 berikut ini :

Tabel -3

Tingkat Usia Responden PDAM Tirta Musi Unit Rambutan Palembang.

\begin{tabular}{|c|c|c|}
\hline $\begin{array}{c}\text { Tingkat } \\
\text { Pendidikan }\end{array}$ & Jumlah & $\begin{array}{c}\text { Persentase } \\
\mathbf{\%}\end{array}$ \\
\hline$<20$ Tahun & 5 & $\mathbf{1 2 , 5}$ \\
\hline 21-30 Tahun & 12 & $\mathbf{3 0}$ \\
\hline 31-40 Tahun & 15 & $\mathbf{3 7 , 5}$ \\
\hline 41-50 Tahun & 8 & $\mathbf{2 0}$ \\
\hline & $\mathbf{4 0}$ & $\mathbf{1 0 0} \%$ \\
\hline
\end{tabular}

Sumber : PDAM Tirta Musi Unit Rambutan 
Dari Tabel-3 dapat dilihat bahwa sebagian besar karyawan kantor PDAM Tirta Musi Unit Rambutan Palembang yang menjadi responden dalam penelitian ini adalah karyawan yang berusia sekitar 31-40 tahun yaitu berjumlah 15 orang atau $37,5 \%$, karyawan yang berusia 21-30 tahun berjumlah 12 orang atau $30 \%$, karyawan yang berusia 41-50 tahun berjumlah 8 orang atau $20 \%$ yang paling sedikit adalah pegawai yang berusia 20 tahun yang berjumlah 5 orang atau $12,5 \%$.

- Responden Menurut Masa Kerja

Tabel -4

Tingkat Masa Kerja Responden PDAM Tirta Musi Unit Rambutan Palembang.

\begin{tabular}{|cc|c|c|}
\hline \multicolumn{2}{|c|}{$\begin{array}{c}\text { Tingkat } \\
\text { Pendidikan }\end{array}$} & Jumlah & $\begin{array}{c}\text { Persentase } \\
\%\end{array}$ \\
\hline $1-5$ & Tahun & 16 & $\mathbf{4 0}$ \\
\hline $6-10$ & Tahun & 12 & $\mathbf{3 0}$ \\
\hline $11-15$ & Tahun & 7 & $\mathbf{1 7 , 5}$ \\
\hline $16-20$ & Tahun & 5 & $\mathbf{1 2 , 5}$ \\
\hline & & $\mathbf{4 0}$ & $\mathbf{1 0 0} \%$ \\
\hline
\end{tabular}

Sumber : PDAM Tirta Musi Unit Rambutan Palembang

Dari Tabel-4 dapat dilihat bahwa masa kerja sebagian besar pegawai Kantor Basarnas Sumatera Selatan yang menjadi responden dalam penelitian ini adalah pegawai yang bekerja antara 1-5 tahun adalah berjumlah 16 orang atau sebesar $40 \%$, karyawan yang bekerja antara 6-10 tahun berjumlah 12 orang atau $30 \%$ dan 11 15 tahun adalah masing-masing 7 orang atau $17,5 \%$ dan karyawani yang masa kerja berkisar 16-20 tahun sebanyak 5 orang atau $12,5 \%$.

\subsection{Rekapitulasi jawaban responden}

- Variabel Motivasi (X)

a. Setiap karyawan mendapatkan gaji sesuai UMR yang di tetapkan

\begin{tabular}{|c|c|c|}
\hline \multirow[t]{2}{*}{ Pernyataan } & \multicolumn{2}{|c|}{ Responden } \\
\hline & Frekuensi & $\%$ \\
\hline Sangat Setuju & 9 & 22,5 \\
\hline Setuju & 6 & 15 \\
\hline Kurang Setuju & 12 & 30 \\
\hline Tidak Setuju & 10 & 25 \\
\hline $\begin{array}{ll}\text { Sangat } & \text { Tidak } \\
\text { Setuju } & \end{array}$ & 3 & 7,5 \\
\hline Jumlah & 40 & 100 \\
\hline
\end{tabular}

Sumber : Diolah dari hasil penelitian 2017

Hasil responden mengenai pemimpin selalu berusaha menselaraskan kepentingan dan tujuan pribadi dengan kepentingan instansi adalah sebanyak 9 responden atau sebesar $22,5 \%$ menyantakan sangat setuju, 6 responden atau sebesar $15 \%$ menyatakan setuju, 10 responden atau sebesar $25 \%$ menyatakan tidak setuju , 3 responden atau sebesar 7,5\% menyatakan sangat tidak setuju .

b. Apakah instansi selalu memperhatikan keselamatan dan keamanan anda kepentingan istansi

\begin{tabular}{|l|c|c|}
\hline \multirow{2}{*}{\multicolumn{1}{|c|}{ Pernyataan }} & \multicolumn{2}{c|}{ Responden } \\
\cline { 2 - 3 } & Frekuensi & \% \\
\hline Sangat Setuju & 16 & 40 \\
\hline Setuju & 22 & 55 \\
\hline Kurang Setuju & 2 & 5 \\
\hline Tidak Setuju & 0 & - \\
\hline $\begin{array}{l}\text { Sangat Tidak } \\
\text { Setuju }\end{array}$ & 0 & - \\
\hline \multicolumn{1}{|c|}{ Jumlah } & $\mathbf{4 0}$ & $\mathbf{1 0 0}$ \\
\hline
\end{tabular}

Sumber : Diolah dari hasil penelitian 2017

Hasil responden pemimpin mau mendengarkan pendapat, kritik dan saran dari bawahan mendapat respon sebagai berikut : sebanyak 16 responden atau sebesar $40 \%$ menyatakan sangat setuju, 22 responden atau sebesar $55 \%$ menyatakan setuju, 2 responden atau sebesar 5\% 
menyatakan kurang Hal ini memperlihatkan bahwa variabel dari ciri tersebut atas motivasi demokratis ada pada pimpinan saat ini dan yang dirasakan oleh para responden yakni adalah karyawan PT. PDAM Tirta Musi Unit Rambutan Palembang

Memberikan penghargaan bagi
karyawan yang berprestasi akan
memberi motivasikaryawan

\begin{tabular}{|l|c|c|}
\hline \multirow{2}{*}{ Pernyataan } & \multicolumn{2}{c|}{ Responden } \\
\cline { 2 - 3 } & Frekuensi & \% \\
\hline Sangat Setuju & 14 & 34 \\
\hline Setuju & 10 & 25 \\
\hline Kurang Setuju & 11 & 28 \\
\hline Tidak Setuju & 5 & 13 \\
\hline $\begin{array}{l}\text { Sangat Tidak } \\
\text { Setuju }\end{array}$ & - & - \\
\hline \multicolumn{1}{|c|}{ Jumlah } & $\mathbf{4 0}$ & $\mathbf{1 0 0}$ \\
\hline
\end{tabular}

Sumber : Diolah dari hasil penelitian 2017

Hasil responden mengenai pemimpin Memberikan penghargaan bagi karyawan yang berprestasi akan memberi motivasi karyawan adalah sebanyak 14 responden atau sebesar 34\% menyantakan sangat setuju, 10 responden atau sebesar $25 \%$ menyatakan setuju, 11 responden atau sebesar $28 \%$ menyatakan tidak setuju , 5 responden atau sebesar $13 \%$ menyatakan sangat tidak setuju

d. Atasan memberikan pelatihan pelatihan kepada karyawan untuk meningkatkan kemampuan dan ketrampilan

\begin{tabular}{|l|c|c|}
\hline \multicolumn{1}{|c|}{ Pernyataan } & \multicolumn{2}{c|}{ Responden } \\
\cline { 2 - 3 } & Frekuensi & \% \\
\hline Sangat Setuju & 21 & 52,5 \\
\hline Setuju & 9 & 22,5 \\
\hline Kurang Setuju & 6 & 15 \\
\hline Tidak Setuju & 4 & 10 \\
\hline $\begin{array}{l}\text { Sangat Tidak } \\
\text { Setuju }\end{array}$ & & \\
\hline \multicolumn{1}{|c|}{ Jumlah } & $\mathbf{4 0}$ & $\mathbf{1 0 0}$ \\
\hline
\end{tabular}

Sumber : Diolah dari hasil penelitian 2017

Hasil responden mengenai Atasan memberikan pelatihan - pelatihan kepada karyawan untuk meningkatkan kemampuan dan ketrampilan mungkin untuk pekerjaan mendapatkan respon sebagai berikut : 21 responden atau sekitar 52,5\% menyatakan sangat setuju, 9 responden atau sekitar 22,5\% menyatakan setuju, 6 responden atau sebesar 15\% menyatakan kurang setuju dan hanya 4 responden atau 10\% menyatakan tidak setuju. Hal ini memperlihatkan bahwa variabel dari motivasi dirasakan oleh PT.PDAM Tirta Musi Unit Rambutan Palembang.

e. Atasan selalu memberikan perhatian kepada karyawan

\begin{tabular}{|l|c|c|}
\hline \multirow{2}{*}{ Pernyataan } & \multicolumn{2}{c|}{ Responden } \\
\cline { 2 - 3 } & Frekuensi & \% \\
\hline Sangat Setuju & 29 & 43,3 \\
\hline Setuju & 26 & 39,5 \\
\hline Kurang Setuju & 8 & 12,3 \\
\hline Tidak Setuju & 3 & 4,5 \\
\hline $\begin{array}{l}\text { Sangat Tidak } \\
\text { Setuju }\end{array}$ & 2 & 4,4 \\
\hline \multicolumn{1}{|c|}{ Jumlah } & $\mathbf{4 0}$ & $\mathbf{1 0 0}$ \\
\hline
\end{tabular}

Sumber : Diolah dari hasil penelitian 2017

Hasil responden mendapatkan Atasan selalu memberikan perhatian kepada karyawan respon sebagai berikut : 29 responden atau sebesar 43,3\% menyatakan sangat setuju, 26 responden atau sebesar $39,5 \%$ menyatakan setuju dan 8 responden atau sebesar $12,3 \%$ menyatakan kurang setuju dan hanya 3 responden atau sebesar 4,5\% menyatakan tidak setuju, jadi dapat disimpulkan bahwa variabel dari gaya kepemimpinan demokratis tersebut mendapat respon sekitar $83,3 \%$ responden menyatakan bahwa sifat yang disebutkan diatas merupakan gaya kepemimpinan dari 
pimpinan basarnas sumatera selatan yang ada saat ini. Hanya $16,5 \%$ saja yang kurang setuju/tidak setuju mengenai penyataan tersebut.

- Variabel Prestasi Kerja (Y)

a. Setiap kali bapak/ibu diberikan tugas yang cukup banyak apakah bapak/ibu bersedia untuk menyelesaikannya

\begin{tabular}{|l|c|c|}
\hline \multirow{2}{*}{\multicolumn{1}{|c|}{ Pernyataan }} & \multicolumn{2}{c|}{ Responden } \\
\cline { 2 - 3 } & Frekuensi & $\mathbf{\%}$ \\
\hline Sangat Setuju & 9 & 13,6 \\
\hline Setuju & 26 & 39,4 \\
\hline Kurang Setuju & 5 & 12,5 \\
\hline Tidak Setuju & - & - \\
\hline $\begin{array}{l}\text { Sangat Tidak } \\
\text { Setuju }\end{array}$ & - & - \\
\hline \multicolumn{1}{|c|}{ Jumlah } & $\mathbf{4 0}$ & $\mathbf{1 0 0}$ \\
\hline
\end{tabular}

Sumber : Diolah dari hasil penelitian 2017

Hasil responden mengenai pemimpin sangat sabar menghadapi tingkah laku bawahanya mendapat respon sebagai berikut : sebanyak 9 responden atau sebesar $13,6 \%$ menyatkan sangat setuju, 26 responden atau sebesar 39,4\% menyatakan setuju, 5 responden atau sebesar 12,5\% menyatakan kurang setuju, Hal ini memperlihatkan bahwa variabel ciri gaya kepemimpinan diplomatis tersebut mendapatkan respon sebesar 53\% yang menyatakan setuju dengan pernyataan diatas.

b. Dalam menyelesaikan tugas yang diberikan bapak/ibu selalu menyelesaikan tugas dengan baik dan tepat

\begin{tabular}{|l|c|c|}
\hline \multirow{2}{*}{ Pernyataan } & \multicolumn{2}{c|}{ Responden } \\
\cline { 2 - 3 } & Frekuensi & \% \\
\hline Sangat Setuju & 13 & 32,5 \\
\hline Setuju & 19 & 5 \\
\hline Kurang Setuju & 2 & 47,5 \\
\hline Tidak Setuju & 4 & 10 \\
\hline Sangat Tidak & 2 & 5 \\
\hline
\end{tabular}

\begin{tabular}{|c|c|c|}
\hline Setuju & & \\
\hline Jumlah & $\mathbf{4 0}$ & $\mathbf{1 0 0}$ \\
\hline
\end{tabular}

Sumber : Diolah dari hasil penelitian 2017

Hasil responden Dalam menyelesaikan tugas yang diberikan bapak/ibu selalu menyelesaikan tugas dengan baik dan tepat mendapat respon sebagai berikut : sebanyak 13 responden atau sebesar 32,5\% menyatakan sangat setuju, 2 responden atau sebesar 5\% menyatakan setuju 2 responden atau sebesar $47,5 \%$ menyatakan kurang setuju dan 4 responden atau $10 \%$ menyatakan tidak setuju. Hal ini memperlihatkan bahw indikator kinerja pegawai tersebut mendapatkan respon 48\% setuju atau dapat dikatakan baik dan banyaknya pekerjaan yang dilakukansetiapharinya.

c. Bapak/ibu mampu mencapai target dari yang di tetapkan perusahaan

\begin{tabular}{|l|c|c|}
\hline \multirow{2}{*}{\multicolumn{1}{|c|}{ Pernyataan }} & \multicolumn{2}{c|}{ Responden } \\
\cline { 2 - 3 } & Frekuensi & \% \\
\hline Sangat Setuju & 16 & 40 \\
\hline Setuju & 14 & 35 \\
\hline Kurang Setuju & 4 & 10 \\
\hline Tidak Setuju & 6 & 15 \\
\hline $\begin{array}{l}\text { Sangat Tidak } \\
\text { Setuju }\end{array}$ & - & - \\
\hline \multicolumn{1}{|c|}{ Jumlah } & $\mathbf{4 0}$ & $\mathbf{1 0 0}$ \\
\hline
\end{tabular}

Sumber : Diolah dari hasil penelitian 2017

Hasil responden Bapak/ibu mampu mencapai target dari yang di tetapkan perusahaan mendapatkan respon sebagai berikut : sebanyak 16 responden atau sebanyak 40\% menyatakan sangat setuju, 14 responden atau sebesar 35\% menyatakan setuju, 4 responden atau sebanyak 10\% menyatakan kurang setuju dan masing masing 6 responden menyatakan tidak setuju atau sebesar 15\%, Hal ini memperlihatkan bahwa indikator prestasi kerja karyawan 
tersebut mendapatkan respon sekitar 57\% menyatkan setuju atau dapat dikatakan baik dalam melaksakan tugas rutin atau tugas khusus dengan tepat waktu.

d. Bapak/ibu selalu hadir tepat waktu dan selalu bersedia mengerjakan tugas yang diberikan

\begin{tabular}{|l|c|c|}
\hline \multirow{2}{*}{ Pernyataan } & \multicolumn{2}{c|}{ Responden } \\
\cline { 2 - 3 } & Frekuensi & \% \\
\hline Sangat Setuju & 14 & 35 \\
\hline Setuju & 10 & 25 \\
\hline Kurang Setuju & 6 & 15 \\
\hline Tidak Setuju & 6 & 15 \\
\hline $\begin{array}{l}\text { Sangat Tidak } \\
\text { Setuju }\end{array}$ & 4 & 10 \\
\hline \multicolumn{1}{|c|}{ Jumlah } & $\mathbf{4 0}$ & $\mathbf{1 0 0}$ \\
\hline
\end{tabular}

Sumber : Diolah dari hasil penelitian 2017

Hasil responden untuk prestasi kerja mengenai Bapak/ibu selalu hadir tepat waktu dan selalu bersedia mengerjakan tugas yang diberikan mendapatkan respon sebagai berikut : sebanyak 14 responden atau sekitar 35\% menyatakan sangat setuju, 10 responden atau sebesar $25 \%$ menyatakan setuju. 6 responden atau sebesar 15\% menyatakan tidak setuju dan masing masing 4 responden atau $10 \%$ yang menyatkan sangat tidak setuju, Hal ini memperlihatkan bahwa indikator prestasi kerja tersebut mendapatkan respon sekitar $47 \%$ setuju atau dapat dikatakan baik dalam menggunakan fasilitas yang ada di instansi untuk menunjang pekerjaan.

e. Karyawan PDAM Tirta Musi selalu menciptakan hubungan kerja yang harmonis dalam bekerja

\begin{tabular}{|l|c|c|}
\hline \multirow{2}{*}{\multicolumn{1}{|c|}{ Pernyataan }} & \multicolumn{2}{c|}{ Responden } \\
\cline { 2 - 3 } & Frekuensi & \% \\
\hline Sangat Setuju & 17 & 42,5 \\
\hline Setuju & 15 & 37,5 \\
\hline Kurang Setuju & 3 & 7,5 \\
\hline Tidak Setuju & 3 & 7,5 \\
\hline
\end{tabular}

\begin{tabular}{|c|c|c|}
\hline $\begin{array}{l}\text { Sangat Tidak } \\
\text { Setuju }\end{array}$ & 2 & 5 \\
\hline Jumlah & $\mathbf{4 0}$ & $\mathbf{1 0 0}$ \\
\hline
\end{tabular}

Sumber : Diolah dari hasil penelitian 2017

Hasil responden untuk prestasi kerja mengenai Karyawan PDAM Tirta Musi selalu menciptakan hubungan kerja yang harmonis dalam bekerja mendapatkan respon sebagai berikut : sebanyak 17 responden atau sebesar $42,5 \%$ Menyatakan sangat setuju, 15 responden atau sebesar $37.5 \%$ menyatakan setuju, 3 responden atau sebesar 7,5\% menyatakan kurang setuju dan 3 responden atau sebesar 7,5\% juga menyatakan tidak setuju. Dan 2 responden menyatakan sangat tidak setuju atau sebesar 5\% Hal ini memperlihatkan bahwa indikator kinerja pegawai tersebut berdampak positif mendapatkan respon sekitar 50\% setuju atau dapat dikatakan baik untuk komitmen serta tanggung jawab karyawan dalam bekerja.

\subsection{Analisis Data \\ - Uji Validitas}

Uji validitas ini dilakukan dengan tujuan untuk mengetahui kesahihan dari kuesioner. Kesahihan disini mempunyai arti kuesioner yang dipergunakan mampu untuk mengukur apa yang seharusnya diukur. Suatu kuesioner dikatakan valid (handal) jika jawaban seseorang terhadap pertanyaan yang terdapat dalam kuesioner tersebut konsisten atau stabil dari waktu ke waktu. Uji validitas ini bisa dilakukan dengan membandingkan nilai $r$ hitung dengan nilai $r$ tabel.

Nilai r hitung diambil dari output
SPSS Cronbach Alpha pada kolom
Correlated Iem-Total Corelation. Sedangkan
nilai $\mathrm{r}$ tabel diambil dengan menggunakan
rumus df $=\mathrm{n}-2$ (Ghozali,2006). Yaitu df $=$
$40-2=38$, sehingga menghasilkan nilai $\mathrm{r}$
tabel sebesar $\mathbf{0 . 3 1 2}$ Untuk hasil lengkap dari


uji validitas dapat dilihat pada tabel- 5 berikut

Tabel-3

Item-Total Statistics (X)

\begin{tabular}{|l|r|l|r|l|}
\hline & $\begin{array}{l}\text { Scale Mean } \\
\text { if Item } \\
\text { Deleted }\end{array}$ & $\begin{array}{l}\text { Scale } \\
\text { Variance if } \\
\text { Item } \\
\text { Deleted }\end{array}$ & $\begin{array}{l}\text { Corrected } \\
\text { Item-Total } \\
\text { Correlation }\end{array}$ & $\begin{array}{l}\text { Cronbach's } \\
\text { Alpha if } \\
\text { Item } \\
\text { Deleted }\end{array}$ \\
\hline Motivasi_1 & 54,23 & 99,475 &, 357 &, 720 \\
Motivasi_2 & 53,96 & 95,646 &, 519 &, 704 \\
Motivasi_3 & 54,00 & 94,863 &, 526 &, 701 \\
Motivasi_4 & 54,04 & 95,567 &, 623 &, 699 \\
motivasi_5 & 53,98 & 99,274 &, 398 &, 717 \\
Score_Total & 28,60 & 28,167 &, 922 &, 727 \\
\hline
\end{tabular}

Tabel-4

Hasil Uji Validitas (X)

Variabel Motivasi (X)

\begin{tabular}{|c|c|c|c|}
\hline No.Item & $\mathbf{r}_{\mathbf{x y}}$ & $\mathbf{r}_{\text {tabel }}$ & Keterangan \\
\hline 1 & 0,720 & 0.312 & Valid \\
\hline 2 & 0,704 & 0.312 & Valid \\
\hline 3 & 0,701 & 0.312 & Valid \\
\hline 4 & 0,699 & 0.312 & Valid \\
\hline 5 & 0,717 & 0.312 & Valid \\
\hline
\end{tabular}

Sumber : PDAM Tirta Musi Unit Rambutan Palembang

Dari tabel 6 Hasil Validitas (X) diatas dapat dilihat bahwa nilai dari $\mathrm{r}$ hitung keseluruhan indikator yang diuji bernilai positif dan lebih besar dari nilai $r$ tabel yang besarnya adalah 0,312. Karena keseluruhan nilai $r$ hitung semua indikator yang diuji lebih besar daripada nilai $r$ tabel, maka dapat diambil kesimpulan bahwa semua butir indikator dalam penelitian ini dinyatakan valid.

Tabel-5

Item-Total Statistics (Y)

\begin{tabular}{|l|r|r|r|r|}
\hline & $\begin{array}{l}\text { Scale Mean } \\
\text { if Item } \\
\text { Deleted }\end{array}$ & $\begin{array}{l}\text { Scale } \\
\text { Variance if } \\
\text { Item } \\
\text { Deleted }\end{array}$ & $\begin{array}{l}\text { Corrected } \\
\text { Item-Total } \\
\text { Correlation }\end{array}$ & $\begin{array}{l}\text { lronbach's } \\
\text { Alpha if } \\
\text { Item } \\
\text { Deleted }\end{array}$ \\
\hline Prestasi Kerja_6 & 55,06 & 90,683 &, 382 &, 731 \\
Prestasi Kerja_7 & 54,67 & 88,617 &, 471 &, 722 \\
Prestasi Kerja_8 & 54,81 & 86,551 &, 562 &, 713 \\
Prestasi Kerja_9 & 55,04 & 87,293 &, 623 &, 712 \\
Prestasi Kerja_10 & 54,94 & 91,271 &, 356 &, 733 \\
Score_Total & 29,29 & 24,915 & 1,000 &, 740 \\
\hline
\end{tabular}


Tabel-6

Hasil Uji Validitas (Y)

Prestasi Kerja (Y)

\begin{tabular}{|c|c|c|c|}
\hline No.Item & $\mathbf{r}_{\mathbf{x y}}$ & $\mathbf{r}_{\text {tabel }}$ & Keterangan \\
\hline 9 & 0,731 & 0.312 & Valid \\
\hline 10 & 0,722 & 0.312 & Valid \\
\hline 11 & 0,713 & 0.312 & Valid \\
\hline 12 & 0,712 & 0.312 & Valid \\
\hline 13 & 0,733 & 0.312 & Valid \\
\hline 14 & 0,705 & 0.312 & Valid \\
\hline 15 & 0,740 & 0.312 & Valid \\
\hline
\end{tabular}

Sumber : PDAM Tirta Musi Unit Rambutan Palembang

Dari tabel -9 Hasil Validitas (Y) diatas dapat dilihat bahwa nilai dari $r$ hitung keseluruhan indikator yang diuji bernilai positif dan lebih besar dari nilai $r$ tabel yang besarnya adalah 0,312. Karena keseluruhan nilai $r$ hitung semua indikator yang diuji lebih besar daripada nilai $\mathrm{r}$ tabel, maka dapat diambil kesimpulan bahwa semua butir indikator dalam penelitian ini dinyatakan valid.

\subsection{Uji reliabilitas variabel Budaya Organisasi dan Kinerja Karyawan}

Setelah peneliti melakukan uji validitas dilanjutkan kepada uji reliabilitas yakni untuk mengecek atau mengetahui apakah kedua variabel yang digunakan peneliti reliabilitas atau tidak. Menurut Nurgiyantoro (2002 : 329), dalam bukunya Statistik Terapan untuk mengukur atau menguji reliabilitas kuisioner dalam penelitian digunakan "Metode Alpha Cronbach"

Reliabilitas menunjukkan suatu instrument yang dapat digunakan sebagai alat pengumpul data,karena instrumen dapat dipercaya dan reliable yang akan menghasilkan data yang dapat dipercaya . Suatu instrument dikatakan reliabel apabila maemiliki nilai cronbach's alpha $(\alpha)>0,60$ (Imam Ghozali,2007:42).

Tabel-7

Reliability Statictics

Motivasi (X)

\begin{tabular}{|r|r|}
\hline Cronbach's Alpha & N of Items \\
\hline, 731 & 9 \\
\hline
\end{tabular}

Sumber : Data Diolah,SPSS 15, 2015

Tabel-8

Reliability Statictics

Prestasi Kerja Karyawan (Y)

\begin{tabular}{|r|r|}
\hline Cronbach's Alpha & N of Items \\
\hline, 743 & 9 \\
\hline
\end{tabular}

Sumber : Data Diolah,SPSS 15, 2015

Berdasarkan tabel 7 dan 8 yakni hasil pengolahan data mengenai realibilitas dianggap reliabel sebab nilai cronbranch alpha sudah diatas $\mathbf{0 , 6 0}$. 


\section{TABEL-9 \\ RELIABILITAS VARIABEL PENGARUH MOTIVASI \\ TERHADAP PRESTASI KERJA KARYAWAN}

\begin{tabular}{|c|c|c|c|}
\hline Variabel & $\begin{array}{c}\text { Nilai Cronbach } \\
\text { Alpha }\end{array}$ & $\mathbf{r}_{\text {tabel }}$ & Keterangan \\
\hline Motivasi (X) & 0,731 & 0,312 & Valid \\
\hline Prestasi Kerja (Y) & 0,743 & 0,312 & Valid \\
\hline
\end{tabular}

Sumber : Data kuesioner yang telah diolah Tahun 2017

Dari tabel diatas dapat dilihat bahwa nilai dari $r$ hitung keseluruhan indikator yang diuji bernilai positif dan lebih besar dari nilai $r$ tabel yang besarnya adalah 0,312 Karena keseluruhan nilai $r$ hitung semua indikator yang diuji lebih besar daripada nilai $r$ tabel, maka dapat diambil kesimpulan bahwa semua butir indikator dalam penelitian ini dinyatakan valid.

\subsection{Analisis Regresi Linier Sederhana}

Berdasarkan hasil analisis data dalam penelitian ini menggunakan metode regresi linier sederhana, dimana variabel-variabel independen yang diduga mempengaruhi budya organisasi dibatasi satu variabel saja. Hasil analisis dengan model regresi linier sederhana terhadap prestasi kerja karyawan (Y) sebagai dependen dengan variabel Motivasi (X) sebagai independen variabel, secara lengkap ditampilkan Motivasi (X) sebagai independen variabel, secara lengkap ditampilkan pada tabel berikut :

Tabel-10

Variables Entered/Removed(b)

\begin{tabular}{|l|l|l|l|}
\hline Model & Variables Entered & $\begin{array}{l}\text { Variables } \\
\text { Removed }\end{array}$ & Method \\
\hline 1 & Motivasi_X (a) & & Enter \\
\hline
\end{tabular}

a All requested variables entered.

b Dependent Variable: prestasi kerja_Y

\section{- Tabel Pada Variables Entered/} Removed $^{b}$ :

Menunjukkan variabel apa saja yang diproses, mana yang menjadi vaariabel bebas dan variabel terikat:

Variabel bebas : Motivasi (X)

Variabeal Terikat : Prestasi Kerja (Y)

Analisis regresi linear sederhana merupakan salah satu metode regresi yang dapat dipakai sebagai alat inferensi statistik untuk menentukan pengaruh sebuah variabel bebas (independen) terhadap variabel terikat (dependen). Uji Regresi linear sederhana ataupun regresi linier berganda pada intinya memiliki beberapa tujuan, yaitu:

1. Menghitung nilai estimasi rata-rata dan nilai variabel terikat berdasarkan pada nilai variabel bebas.

2. Menguji hipotesis karakteristik dependens

3. Meramalkan nilai rata-rata variabel bebas dengan didasarkan pada nilai variabel bebas diluar jangkaun sample

Pada analisis regresi sederhana dengan menggunakan SPSS ada beberapa 
asumsi dan persyaratan yang perlu diperiksa dan diuji, beberapa diantaranya adalah :

1. Variabel bebas tidak berkorelasi dengan disturbance term (Error). Nilai disturbance term sebesar 0 atau dengan simbol sebagai berikut: E (U / $\mathrm{X})=0$,

2. Jika variabel bebas lebih dari satu, maka antara variabel bebas (explanatory) tidak ada hubungan linier yang nyata,

3. Model regresi dikatakan layak jika angka signifikansi pada ANOVA sebesar $<0.05$, Predictor yang digunakan sebagai variabel bebas harus layak. Kelayakan ini diketahui jika angka Standard Error of Estimate $<$ Standard Deviation,
4. Koefisien regresi harus signifikan. Pengujian dilakukan dengan Uji $\mathrm{T}$. Koefesien regresi signifikan jika $\mathrm{T}$ hitung $>$ T table (nilai kritis),

5. Model regresi dapat diterangkan dengan menggunakan nilai koefisien determinasi $(\mathrm{KD}=\mathrm{R}$ Square $\mathrm{x}$ $100 \%$ ) semakin besar nilai tersebut maka model semakin baik. Jika nilai mendekati 1 maka model regresi semakin baik

6. Residual harus berdistribusi normal,

7. Data berskala interval atau rasio,

Kedua variabel bersifat dependen, artinya satu variabel merupakan variabel bebas (variabel predictor) sedang variabel lainnya variabel terikat (variabel responden).

\section{Tabel-11}

Coefficients

\begin{tabular}{|c|c|c|c|c|c|c|}
\hline \multirow[b]{2}{*}{$\begin{array}{l}\text { Mode } \\
1\end{array}$} & & \multicolumn{2}{|c|}{$\begin{array}{l}\text { Unstandardized } \\
\text { Coefficients }\end{array}$} & \multirow{2}{*}{$\begin{array}{l}\text { Standardized } \\
\text { Coefficients } \\
\text { Beta }\end{array}$} & \multirow{2}{*}{$\mathrm{t}$} & \multirow{2}{*}{\begin{tabular}{|l|} 
Sig. \\
Std. \\
Error
\end{tabular}} \\
\hline & & B & $\begin{array}{l}\text { Std. } \\
\text { Error }\end{array}$ & & & \\
\hline 1 & (Constant & 21,077 & 3,722 & & 5,662 & ,000 \\
\hline & $\begin{array}{l}\text { Motivasi } \\
\text { X }\end{array}$ & 283 & 126 & ,302 & 2,242 & ,029 \\
\hline
\end{tabular}

Sumber : Data Diolah,SPSS 15, 2015

\section{- Tabel Cooefficients ${ }^{a}$}

Metode persamaan regresi yang diperoleh dengan koefisien konstanta dan koefisien variabel yang ada di kolom understandarized koefisien B, yaitu :

$\mathbf{Y}=\mathbf{2 1 , 0 7 7}+\mathbf{0 , 2 8 3} \mathrm{X}$

Persamaan regresi tersebut dapat dijelaskan sebagai berikut :

a. $=21,077$ merupakan nilai konstanta, jika nilai variabel $\mathrm{X}$ adalah nol, maka prestasi kerja (Y) sebesar 21,077.

b. $=0,283$ menunjukkan bahwa variabel motivasi $(\mathrm{X})$ berpengaruh positif terhadap prestasi kerja kata lain jika kepuasan terhadap motivasi ditingkatkan 1 satuan maka produktivitas kerja karyawan akan bertambah sebesar 0,283 satuan skala 


\subsection{Analisis korelasi}

Tabel-11

Model Summary

\begin{tabular}{|l|r|r|r|rr|}
\hline Model & R & R Square & $\begin{array}{l}\text { Adjusted } \\
\text { R Square }\end{array}$ & $\begin{array}{l}\text { Std. Error of the } \\
\text { Estimate }\end{array}$ \\
\hline 1 &, $302(\mathrm{a})$ &, 091 &, 073 & & 4,805 \\
\hline
\end{tabular}

a Predictors: (Constant), motivasi_X

Tabel Model Summary :

Menampilkan nilai $\mathrm{R}$ yang merupakan simbol dari nilai koefisien korelasi.

Hasil analisis pengaruh budaya organisasi terhadap kinerja karyawan pada PDAM Tirta musi unit rambutan seperti yang dapat dilihat pada tabel 12 diatas menunjukkan bahwa koefisien korelasi $(\mathrm{R})=0,302$. Hal ini berarti budaya organisasi sangat berhubungan dengan kinerja karyawan karena nilai $\mathrm{R}=0,302$ mendekati 1 .

\subsection{Koefisien Determinasi}

Tabel 15 ini juga memperlihatkan nilai koefisien determinasi (Resquare) yang digunakan untuk mengetahui persentase pengaruh vaariabel independen $(X)$ tehadap variabel dependen (Y) sebesar 0,091. Hal ini berarti bahwa pengaruh budaya organisasi dapat menjelaskan 91\% dari perubahan kinerja karyawan dan sisanya yaitu sebesar $9 \%$ dipengaruhi oleh faktor-faktor yang tidak diteiti.

\subsection{Uji F dan Uji t}

- Uji F

Tabel-15

ANOVA(b)

\begin{tabular}{|c|c|c|c|c|c|c|}
\hline Model & & $\begin{array}{l}\text { Sum of } \\
\text { Squares }\end{array}$ & $\mathrm{df}$ & $\begin{array}{l}\text { Mean } \\
\text { Square }\end{array}$ & $\mathrm{F}$ & Sig. \\
\hline 1 & $\begin{array}{l}\text { Regression } \\
\text { Residual } \\
\text { Total }\end{array}$ & $\begin{array}{l}116,091 \\
1154,582 \\
1270,673\end{array}$ & $\begin{array}{l}1 \\
50 \\
51 \\
\end{array}$ & $\begin{array}{l}116,091 \\
23,092\end{array}$ & 5,027 &, $029(a)$ \\
\hline
\end{tabular}

a Predictors: (Constant), motivasi_X

b Dependent Variable: prestasi kerja_Y

Tabel 15 tersebut menunjukkan hasil dari uji-f yang menghasilkan $\mathrm{F}$ hitung $=$ 5,662 lebih besar dari $F$ tabel $=2,242$. Oleh karena itu dapat disimpulkan bahwa variabel-variabel motivasi berpengaruh secara signifikan terhadap prestasi kerja karyawan PDAM Tirta Musi Unit Rambutan Palembang. Berdasarkan hasil uji F, maka hipotesis dalam penelitian ini yang manduga bahwasannya motivasi berpengaruh positif dan signifikan terhadap prestasi kerja karyawan PDAM Tirta Musi Unit Rambutan Palembang telah terbukti dan dapat diterima.

Digunakan juga untuk menentukan taraf signifikansi atau linieritas dan regresi, kriterianya dapat ditentukan berdasarkan uji $\mathrm{F}$ atau Uji nilai signifikan (sig). Cara yang paling mudah dengan uji sig dengan 
ketentuan. Jika nilai signifikan $<0,05$, maka model regresi adalah linier dan berlaku sebaliknya. Berdasarkan tabel diatas diperoleh sig 0,029, yang berarti $<$ kriteria signifikan $(0,05)$.

Dengan demikian model persamaan regresi berdasarkan data penelitian adalah signifikan, artinya model regresi linier dipengaruhi / memiliki kriteria linieritas.

\section{- $\quad$ Uji-t}

Untuk uji signifikansi pengaruh budaya organisasi terhaadap kinerja karyawan digunakan uji-t (uji student)atau uji parsial dan uji $\mathrm{f}$ (uji fhiser) atau uji simultan. Digunakan untuk menguji tingkat signifikan varabael $\mathrm{X}$ terhadap $\mathrm{Y}$.

Jika 1 hitung $<\mathrm{t}$ abel, maka varibel $\mathrm{X}$ tidak mempunyai keeratan hubungan yang signifikan dengan variabel Y. Berdasarkan pada tabel -11 dapat dilihat hasil perhitungan sebagai berikut :

- Hasil perhitungan untuk motivasi (X) yang menghasilkan $\mathrm{t}$ hitung $=5,662$ ebih besar dari nilai $t_{\text {tabel }}=1,628$

- Hasil perhitungan Prestasi kerja karyawan $(\mathrm{Y})$ yang menghasilkan $\mathrm{t}$ hitung $=2,242$ lebih besar dari nilai $\mathrm{t}$ tabel $=1,628$.

Sehingga dapat disimpulkan bahwa terdapat pengaruh antara motivasi terhadap prestasi kerja karyawan . Berdasarkan hasil uji t, maka hipotesis dalam peneltian ini yang menduga bahwasannya motivasi $(\mathrm{X})$ berpengaruh paling dominan terhadap prestasi kerja PDAM Tirta Musi Unit Rambutan Palembang telah terbukti dan dapat diterima.

\subsection{Pembahasan}

Hasil penelitian ini menunjukkan bahwa PDAM Tirta Musi unit rambutan Palembang dalam katogori baik. Dimana dalam hal ini dapat diketahui bahwa prestasi kerja karyawan akan meningkat.
Pelaksanaan kegiatan dalam katogori sangat baik. Dimana PDAM Tirta Musi Unit rambutran Palembang benarbenar mengaplikasikan kegiatan sesuai dengan konsep yang telah disepakati sehingga karyawan yang mengikuti dapat menangkap dan memahami kegiatan yang diberikan sehingga skill and Knowledge para karyawan mengalami peningkatan. Berdasarkan hasil analisis diatas maka melalui motivasi, prestasi kerja karyawan diharapkan mampu maenjalankan tugas dan pekerjaan mereka dengan baik.

\section{KESIMPULAN DAN SARAN}

\subsection{Kesimpulan}

1. Dari hasil penelitian yang dilakukan, variabel budaya organisasi berpengaruh positif dan signifikan terhadap kinerja karyawan PDAM Tirta Musi Unit Rambutan Palembang telah terbukti dan dapat diterima.

2. Dari hasil penelitian yang dilakukan, variabel yang paling dominan dalam mempengaruhi kinerja karyawan yaitu Motivasi. Dukungan dari manajer sangat mempengaruhi Prestasi kerja karyawan. Dukungan lebih yang diberikan oleh manajer dapat membuat karyawan merasa nyaman dalam bekerja dan karyawan diberi tanggungjaawab lebih sehingga karyawan dapat memaksimalkan kemampuannya untuk bekerja lebih baik

\subsection{Saran-saran}

1. Sebaiknya pihak karyawan PDAM Tirta Musi Unit Rambutan Palembang lebih diintensifkan

2. Hasil dari proses motivasii perusahaan dapat meningkatkan prestasi kerja karyawan. Diharapkan dengan adanya kegiatan tersebut menumbuhkan motivasi dari pimpinan dan calon pimpinan dimasa yang akan datang 


\section{DAFTAR PUSTAKA}

Arikunto, S, 2012. Prosedur Penelitian Suatu

Pendekatan Praktik. Penerbit Rineka Cipta. Jakarta.

Simamora, Bilson, 2013. Memenangkan Pasar Dengan Pemasaran Efektif dan. Profitabel, PT.Gramedia Pustaka Utama, Jakarta.

Cantika, Yuli Sri Budi, 2005. Manajemen Sumber Daya Manusia. UMM Press, Malang

Dessler, Gary, 2013. Manajemen Sumber Daya Manusia, jilid satu, edisi kesepuluh. Terjemahan Paramita Rahayu. 2011. Jakarta Barat : Indeks.

Edy Sutrisno, 2009, Manajemen Sumber Daya Manusia, Jakarta, Kencana. Pernada Media Group

Fahmi, Irham, 2010. Manajemen Kinerja Teori dan Aplikasi. Jakarta : Penerbit Alfabeta.

Ghozali, Imam, 2016. Aplikasi Analisis Multivariate Dengan Program SPSS. Semarang : Badan Penerbit Universitas Diponegoro.

Gomes, Faustino Cardoso, 2013. Manajemen Sumber Daya Manusia. Edisi Kedua. Penerbit Andi Offset, Yogyakarta.

Handoko, T Hani, 2011. Manajemen Personalia dan Sumberdaya Manusia,Edisi. Kedua. BPFE, Yogyakarta.

Handoko, T H, 2010. Manajemen Personalia dan Sumberdaya Manusia. BPFE,. Yogyakarta.

Hasibuan, Melayu. 2015. Manajemen Sumber Daya Manusia, edisi Revisi. Jakarta : Penerbit Bumi Aksara. 